\title{
REMEMBERING OPERACIÓN TRIUNFO
}

\section{A LATIN MUSIC REALITY SHOW IN THE ERA OF TALENT SHOWS}

\author{
Paola Savini \\ Autorità per le garanzie nelle comunicazioni \\ Via Isonzo 21/b \\ Rome 00198 \\ Italy \\ savini.p@live.it
}

\begin{abstract}
The music format Operación Triunfo (2001-2011), which was aired on RTVE for the first time in 2001, started as a television (TV) and musical success in Spain and today is remembered as one of the most famous shows around the world as well as an incredible socio-economic phenomenon in Spanish TV. This paper describes the format concept and results. Both commercial and social aspects are introduced to understand why, after 15 years, it is remembered with nostalgia and remains a shining example of a good communication project and a perfect balance between the global and the local, despite the lack of great success in the following years in Spain and abroad.
\end{abstract}

Keywords: format, Spain, talent shows, music shows

\section{Introduction}

One the biggest European television (TV) successes of the early 2000s was the music format Operación Triunfo (20012011), which was aired on Spain's RTVE network for the first time in 2001, turning into one of the most viewed and prizewinning musical shows on Spanish TV. Developed by Catalan Gestmusic Endemol and the producers Toni Cruz and the Mainat brothers, the format's structure partly evoked Starmaker (2001), a musical reality show born from Dutch John de Mol Produkties (then Endemol) and Popstars (1999-), a musical talent format aired in New Zealand in 1999, and in some ways, also Big Brother (1999-), an Endemol creation.

The show aimed to find the country's representative for the Eurovision Song Contest 2002 in Tallin, and for 113 days it cloistered a selection of 16 young singers in an art school, called the Academia, where these singers were tutored by different professionals to become professionals themselves. Once a week, the contestants took part in a prime-time show, which was called Gala, to sing cover versions of famous pop songs. Through a week by week selection by the TV judges and the audiences at home, after 14 shows, the winner of the competition was named and five other finalists were chosen. Some of them are still very famous in the Spanish and Latin American music markets after 15 years.

This incredible TV success is particularly interesting for TV format history because of the initial success in the country and the ambivalence of the format results abroad, based on the Latin attributes of the communication project (Spanish and South American music, presence of families and friends, paternalistic professors). 
First, the Spanish format has overtaken both Starmaker (2001-2008) and the lucky French adaptation, Star Academy (2012-2013) in terms of its economic results and success. A brilliant operation of TV marketing started from a programme designed for the Spanish market and immediately focused on other Latin markets: Portugal, the vast South American market, and also Italy, where a Spanish anchor hosted the programme (Miguel Bosé). The viewers' reception of these musical reality shows in Italy, however, expressed a failure of the 'Latin' communication project, where a 'banal transnationalism ${ }^{1}$ has been pushed for advertising reasons.

Second, it comes from 'old television,' where the music is the protagonist but is, at the same time, a post-Big Brother reality show with a satellite channel that was completely dedicated to the Academia's guests, and it is a peculiar and solitary Latin case study among the more studied talent formats, such as the Idols series.

Finally, it was able to demonstrate incredible success in the music market, which has not been replicated in Spain or in other countries where the format was adapted, years before digital innovations changed the music market as we knew it then. The first Spanish edition of the programme (hereinafter, called 'OT1'), apart from its commercial success (TV audience, advertising and merchandising), can be remembered as being a real phenomenon for the recording industry, having sold many platinum CDs.

In this paper, the 'uneasy relationship of music and television'2 is first briefly introduced, in order to find a place for music reality shows and musical talent shows among the different kinds of TV programmes in which music plays a role. Music in TV is thus introduced, as it is analysed in film studies as being extradiegetic, intradiegetic, and diegetic. ${ }^{3}$ Second, some of the most famous TV music formats are recalled in order to depict a few peculiarities of the present case study. Then, the production company and the Operación Triunfo format are described. Both commercial and social aspects are introduced in order to understand why, after 15 years, OT1 is still remembered with nostalgia, despite the format itself slowly losing its appeal to the audience. Additionally, after three seasons on the RTVE network, the format was acquired by the private broadcaster Telecinco (for five editions) until it was cancelled in 2011 due to low ratings.

After 15 years from the first adaptation, after eight Spanish editions in over 50 countries in which the format was sold, after a decade of Idols (2001-), X Factors (2004-), and (The) Voice(s) (2010-), and after a new scenario for TV markets that has been opened up by technological innovation and new players, the programme Operación Triunfo still remains a shining example of the potential of the TV format as a communication project and as a perfect balance between the global and local. It is an important page in the history of music in and on TV.

\section{Music on Television}

I don't make culture, I sell it.

Dick Clark $^{4}$

From an historical perspective, TV programming was actually started by radio broadcasters, since, in the United States, the Radio Corporation of America (RCA) was the first to enter the TV business through the National Broadcasting Company (NBC) in 1939. Moreover, in 1941, when the start of commercial TV transmission was authorised by the Federal Communications Commission, the Columbia Broadcasting System (CBS) also started broadcasting. In Europe, the same happened. For instance, in the United Kingdom, the British Broadcasting Company (today the British

\footnotetext{
1 Pia Majbritt Jensen, Andrea Esser, Heidi Keinonen and Anna-Maria Lemor, 'The duality of banal transnationalism and banal nationalism,' New Patterns in Global Television Formats, Intellect Ltd., 2016.

2 Simon Frith, 'Look! Hear! The Uneasy Relationship of Music and Television,' Popular Music, 21 March 2002, pp. 277-90.

3 Ronald Wayne Rodman, Tuning in: American narrative television music, Oxford University Press, 2010.

4 See John Jackson, 'Preface' in American Bandstand: Dick Clark and the Making of a Rock'n'Roll Empire, Oxford University Press, 1997.
} 
Broadcasting Corporation, BBC) entered the TV business in 1936, and in Italy, the Radio Audizioni Italiane (RAI) started experimenting with TV transmission in 1944. Television was in fact also called 'the natural extension of sound' ${ }^{\text {' }}$ ' 'the illustrated radio.' 6

Certainly, it is not for this reason that the relationship between music and TV is a complicated matter, but this is partially due to the osmotic liaison between the professionals of the two worlds of radio and TV broadcasting, which may have had an effect on the initial programming strategies of the second medium. ${ }^{7}$ Music performances were initially derived straight from those of radio, and the costs were amortised. Music programmes, for example Your Hit Parade (19501959) in the United States, came directly from radio. The TV stars were often recruited from among radio stars; Perry Como, Dean Martin, and Frank Sinatra are examples. ${ }^{8}$

Television was born as an audiovisual medium, where the audio component that characterises it was shown in a flow of music, words, and background noise. The flow of sounds made the TV a 'talking machine' that invaded the surrounding environment and that did not require the user's presence in front of the screen. However, audio is more of a way to hook the audience to the screen than the real protagonist of the experience of TV consumption, as is the case with radio consumption. Apart from sounds and words, this is also true for music. ${ }^{9}$ Still, at the same time and for different reasons, it is rare to find TV programmes that are really about music ${ }^{10}$ with some obvious exceptions, particularly in the multichannel world, where radio channels are also broadcast on TV.

As TV is a medium for a generalist audience, or at least it was until the 1980s, before the proliferation of liberalisation and thematic channels due to the availability of digital terrestrial TV, cable, and satellite, it was not easy to find a place for niche genres. On one hand, apart from the classical music orientation of early TV because of the cultural origins of the first TV audiences and, on the other hand, because of the educational aims of public service broadcasters, pop and rock music later dominated TV programming. Pop music and rock n' roll grew and adapted to each other indissolubly with TV. As genres, they undoubtedly owe something to the medium. ${ }^{11}$ Music, which was started as a way to attract audience attention in the first years of broadcasting, slowly took on different roles in relation to both programmes and commercials, since TV entertainment discovered 'youth' in the 1950s.

Today, these different roles for music in and on TV programming can be distinguished, as in film analysis, between 1) the extradiegetic role, which serves as a flow between different programmes, such as in breaks or jingles in commercials or announcements, 2) the intradiegetic role, where music is the background music to a programme, for instance in theme songs or sound tracks, which have different functions, ranging from strictly technical use to aesthetic or functional use (such as the suspense element in formats like Who Wants to Be a Millionaire?), and finally, 3) the diegetic when the music plays a role on screen.

In the latter case, music can be the support or the star of a TV programme, the protagonist of a game, or a 'Warhol' machine to allow us to reach our 15 minutes of fame (a pretext). ${ }^{12}$

Music can be the support of a TV programme, as is the case with music that fits into entertainment programmes, such as complementary use in a ballet, the live performance of a singer that is hosted during a show, or the performance of resident musicians in variety shows or late-night shows. This is the case with one-man shows, such as the

5 Sir William Haley, the BBC's first post-war Director, quoted in Asa Briggs, Sound and Vision: The History of Broadcasting in the United Kingdom: Volume IV, Oxford University Press, 1979, p. 4.

6 Michiel Chion, Claudia Gorbman and Walter Murch, Audio-vision: sound on screen, Columbia University Press, 1994.

7 "During the first decade of the post-war service, there were frequent charges that the BBC was essentially a radio-oriented organization, whose leadership lacked interest in television..." See: Briggs, 1979, p. 213.

8 See Ronald W. Rodman, Television Music.

9 "Music on Television is less often heard for its own sake than as a device to get our visual attention." See: Frith, $2002,280$.

$10 \mathrm{lbid}$.

11 "The advent of rock ' $n$ ' roll [...] was an integral part of America's pop-culture boom, which happened to coincide with the development of network television." See: Jackson, 1997.

12 Alberto Bruno, 'Non solo Sanremo,' Link. Idee per la tv. Musica fuori e dentro la TV, Sperling \& Kupfer, 2003, p. 88. 
P. Savini, Remembering Operación Triunfo

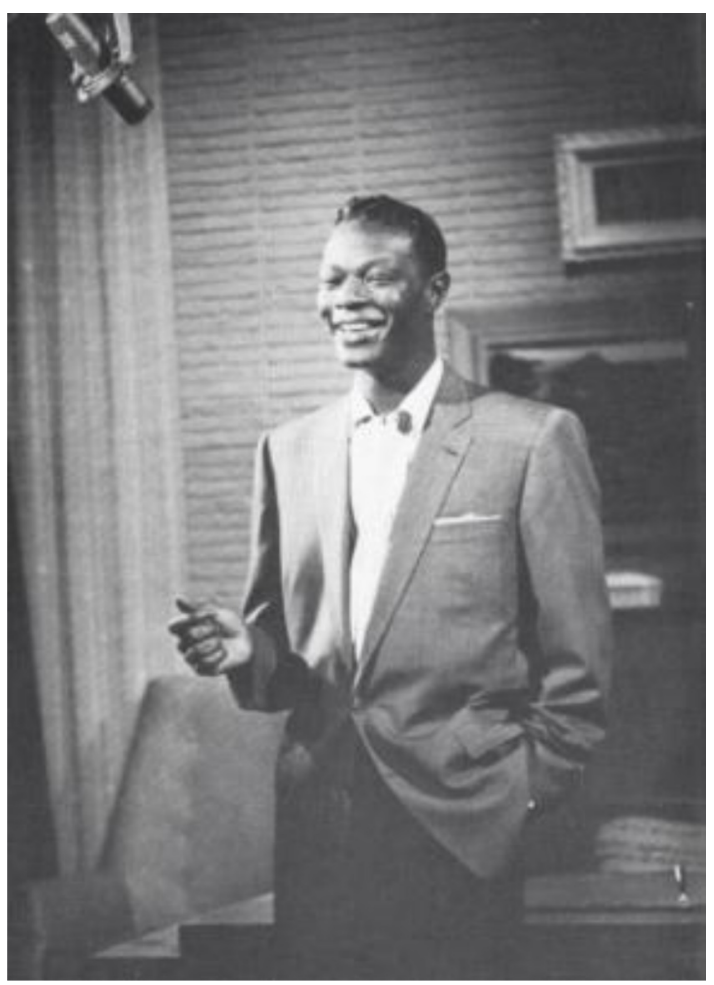

Figure 1. The Nat King Cole Show (1956-1957). Click here to see the source.

musical variety shows of Sinatra (The Frank Sinatra Show, 1950-1952) and Nat 'King' Cole (The Nat King Cole Show, 1956-1957), or the Andy Williams Show (1962-1971) in the United States and the Gianni Morandi and Adriano Celentano shows in Italy. ${ }^{13}$

Music is the star of a TV programme in the case of musical events, where TV has fostered the creation of the event itself or where the event existed first. Here, we find the Eurovision Song Contest (1956-), the Sanremo Music Festival (1951-) in Italy, or the Festival Internacional de la Canción de Benidorm (1959-2006) in Spain.

Video 1. Le canzoni di Sanremo, Cinecittà Luce. Original source: La settimana Incom 01375 del 15/03/1956. Go to the online version of this article to watch the video.

This is also the case with the broadcasting of live concerts, both pop and rock, from stadiums, and classical music in theatres and auditoriums or music performances that are hosted in a TV studio, which is also the case with old programmes, such as Six-Five Special (1957-1958) and Oh Boy! (1958-1959), or long running programmes, such as Top of the Pops (1964-2006 ${ }^{14}$ ) in the United Kingdom or Escala en hi-fi (1961-1967) in Spain.

Video 2. Coldplay perform 'Adventure of a Lifetime' for Christmas Day Top of the Pops on BBC One (25 Dec 2015). See the original source here. Go to the online version of this article to watch the video.

When the music is the protagonist in a game, it includes those game shows in which part of, or the whole series of questions, or the challenges to be overcome are related to the musical world. This is the case with the programme 
P. Savini, Remembering Operación Triunfo

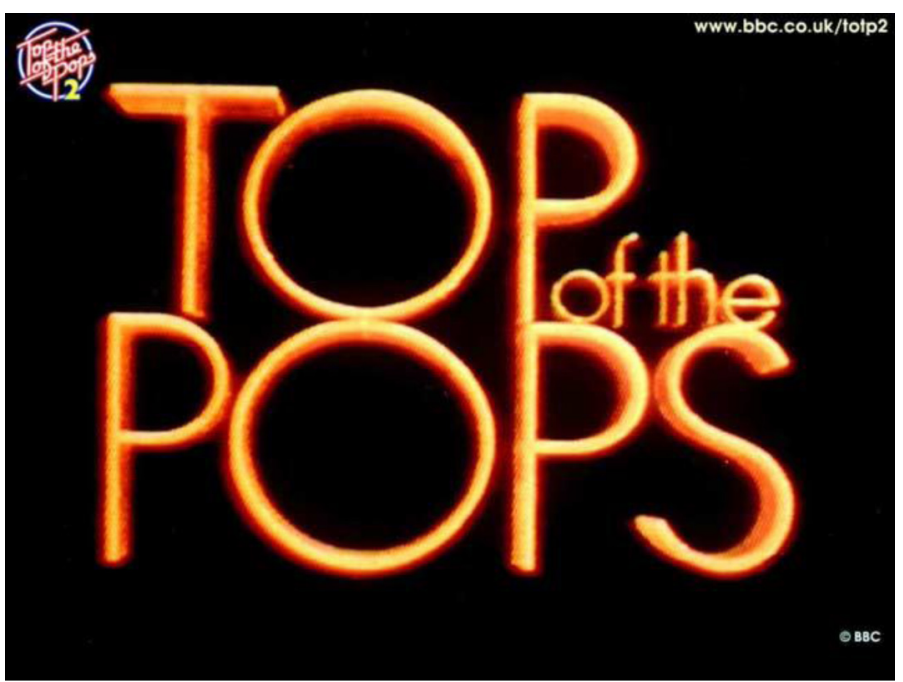

Figure 2. Top of the Pops Logo 1970s. Click here to see the source.

Karaoke $(1992-1995 ; 2015)$ in Italy, in which the singing performance of an amateur is judged by the public.

Additionally, it is the case in some quizzes where the musical culture is to be compared, as in the US format Name That Tune (1952-1985) and the different national versions that have been adapted from it (II Musichiere, 1957-1960, and Sarabanda, 1997-2004, in Italy) or in There Goes That Song Again (1973-1977) in the United Kingdom. ${ }^{15}$

When the music video became an audiovisual product that was aesthetically and formally defined, music and TV found a new commercial affinity between the interests of broadcasters and record companies; this is the case with chart programmes like CD: UK (Count Down: United Kingdom, 1998-2006), The Chart Show (1986-2009), London Live (2006-2013), or the Superclassifica Show (1977-1995) in Italy. This is also the case with entire channels that are devoted to the music video; the most famous example of which is undoubtedly MTV. ${ }^{16}$

Finally, the music is particularly functional in talent shows as a 'Warhol machine' in order to gain 15 minutes of fame. The artistic and narcissistic aspirations to be part of the small screen have generated talent and musical reality shows, such as Popstars, Pop Idol (2001-2003), Fame (2003), El Número Uno (2012-2013), and, of course, Operación Triunfo, where music is the protagonist of the programme, but this is used more as a pretext to be on screen than for other reasons.

\title{
3 Times for Musical Reality Shows
}

\author{
It's the freakiest show
}

David Bowie ${ }^{17}$

15 For an overview of British game shows about music, click here.

16 MTV (Music Television) is an American television channel that is part of the multimedia group Viacom Inc., which was launched in 1981, originally to play music videos and today targeted at teenagers and young adults. Literature about music video and MTV is huge, and is devoted particularly to textual analysis. See, for example, the special issue of the Journal of Communication Inquiry, January 1986, 10:1; Richard L. Baxter et al, 'A Content Analysis of Music Videos,' Journal of Broadcasting \& Electronic Media, 29.3, 1985, pp. 333-40; Saul Austerlitz, Money for Nothing: A History of the Music Video, from the Beatles to the White Stripes, Continuum International Publishing Group, 2007; Simon Frith, Andrew Goodwin and Lawrence Grossberg, Sound and Vision: The Music Video Reader, Routledge, 2005.

17 'Life on Mars?' Hunky Dory, 1971, EMI Records. 
The appropriation of TV by non-experts, and their convergence with the new marketing needs of the post-Big Brother reality shows (i.e. audience participation and ancillary exploitation that are used to maximise revenues) are the basic formula of some of the programmes that have enjoyed particular TV success in many countries in the last two decades.

The ancestors of these programmes can be found in the 'people shows' of the analogue era of broadcasting, such as the family-oriented The Original Amateur Hour (1948-1970) and Tiny Talent Time (1957-1992) in Canada, Young Talent Time (1971-1988) in Australia, the Italian La Corrida (1986-2011), and Hacia la fama (1958-1959), Caras nuevas (1957), and Gente joven (1974-1987) in Spain. This was also the case with the Dutch Soundmix (1985-2002), the British Star for a Night (2000-2001), and Give Your Mate a Break (1999), which vary with respect to the prize, the voting procedures, and the 'talent' required from the performer. The basic formula is to offer TV studios to unknown people in order to make their shows on TV, according to the 'dreams come true' mantra.

We have to look to New Zealand and wait until 1999 for Popstars or better to the Australian adaptation in 2000, to actually have the first successful example of the optimisation of synergies between TV, the music industry, stardom, and strategies for exploitation, which were all founded on the powerful shoulders of a media conglomerate, in this case Warner Music.

Video 3. Popstars, First Episode Television, New Zealand, 1999. Original source: Ngā Taonga Sound \& Vision - TVNZ Collection. Go to the online version of this article to watch the video.

The original concept was produced by Jonathan Dowling who then licensed it to Screentime in Australia, for the search among thousands of aspiring singers for five girls who were suitable to form a pop group, which would be launched under the aegis of the TV show and Warner Music with their first album and concert series sponsored by the Austereo radio network and the production of the magazine New ldeas for the audience of the programme.

In its first Australian edition, the 13 episodes broadcast during the fall of 2000 , the programme reached a share of $53 \%$, and the first group selected, the Bardot, topped the music charts in Australia and New Zealand with their first single, 'Poison' and, before breaking up in 2003, was involved in several successful seasons in terms of both concerts and sales.

After the success came the exploitation abroad; almost every country in Europe and lots of countries on other continents created more or less successful adaptations of this appealing format, which staged big casting sessions in various cities. In 2016, the format is still being aired in Lebanon and Egypt.

In the wake of Popstars, other programmes were created in which the matrix of music, reality, and interactivity was fully exploited. Audience participation from home was easier and more economical, ${ }^{18}$ and just one year after its pop predecessor, Pop Idol invoked audience interactivity and participation through its claim 'But this time, you choose!'19 In one case, the contestants were watched 24 hours a day and trained in different disciplines; in the other, the programme was shown at different hours and on other channels and media. In others, the concept was converted into products such as CDs and magazines. Sometimes, the active participation of the public was required for the selection and elimination of the protagonists, and in some cases, even the most proper marketing decisions were shared, as in the Dutch version of Starmaker, in which the songs and the disk graphics were discussed on the programme's website.

Tracing a precise world map of musical reality shows and talents at the start of 2000 is quite difficult, as all the famous musical formats are different in many small ways, but, simultaneously, they are very similar, and lots of disputes have

18 See: David Selva Ruiz, 'El Televoto Como Fórmula Comercial: El Caso de Operación Triunfo', Comunicación: Revista Internacional de Comunicación Audiovisual, Publicidad Y Estudios Culturales, 2003, 2, pp. 129-46.

19 See Simon Cowell, 'All Together Now! Publics and Participation in American Idol', Invisible Culture, 6, 2003, 1-12; Su Holmes, '“Reality Goes Pop!”: Reality TV, Popular Music, and Narratives of Stardom in Pop Idol', Television \& New Media, 5.2, 2004a, pp. 147-72, and Su, Holmes, '“But This Time You Choose!" Approaching the "Interactive” Audience in Reality TV', International Journal of Cultural Studies, 7.2, 2004 b, pp. 213-31. 
arisen as a result of copying and the scant legal protections under the copyright laws. ${ }^{20}$ Meanwhile, in Spain, a Latin socio-economic TV event was created at the end of 2001.

\section{Operación Triunfo}

A tu lado me siento seguro ${ }^{21}$

Gestmusic Endemol is the format producer of the eight editions of Operación Triunfo. Today it is part of the Endemol Shine Group, more precisely part of its Endemol Shine Iberia division, the umbrella under which all the production companies situated in Spain and Portugal are grouped. ${ }^{22}$ In 1987 in Barcelona, it started as a local production company that was basically dedicated to humour programmes and slowly grew to conquer national channels as well as international markets. When the Spanish producers started working on the Dutch format Starmaker in order to create a product for the national market, no one was expecting such success. ${ }^{23}$ The format was created by Toni Cruz and brothers Josep $\mathrm{M}^{\mathrm{a}}$ Mainat and Juan Ramon Mainat, and it was produced for the Spanish public service broadcaster, RTVE, to be broadcast on the TVE1 and TVE2 channels. ${ }^{24}$ There were 3,900 applicants for the first edition.

The kickoff was on 22 October 2001 in prime time on Monday from 22:00 to 24:00 on TVE1, and was directed by Tinet Rubira with Carlos Lozano as host. A daily strip, called Resumen, was aired from Monday to Friday between 21:30 and 22:00 on TVE2. On Sunday, the Resumen del domingo was aired with Nina (a singer who was also the director of the Academia) as host. After selections in nine towns, 24 aspiring musical talents were hosted in the TV studio during Gala 0 and, of these, 16 were selected to enter as students into the Academia, a school that submitted them to eight hours of daily trials, including dance lessons, singing, acting, and vocal techniques.

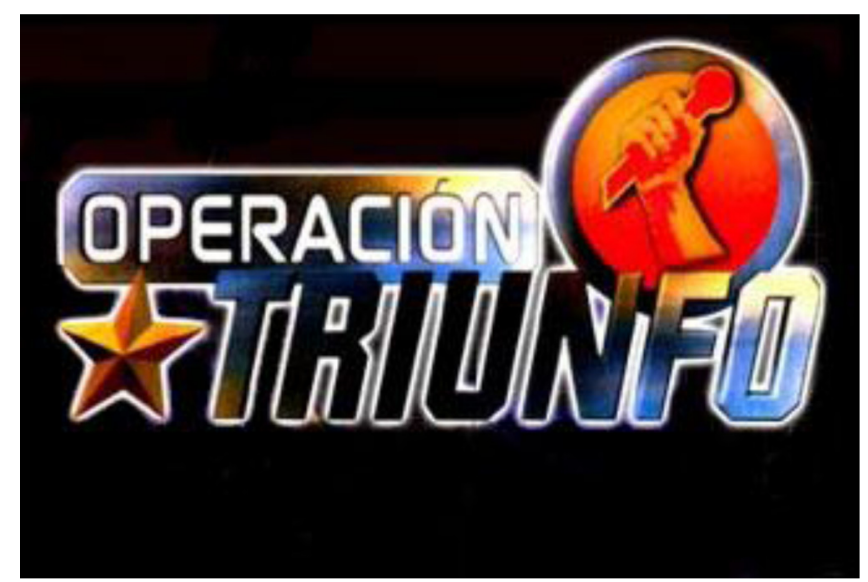

Figure 3. Operación Triunfo 1 - Logo. Source: RTVE.

20 See: Martin Kretschmer, Sukhpreet Singh and JonWardle, The Exploitation of Television Formats, ESRC Digital Resource, Bournemouth University, 2009. The most famous dispute is in the United Kingdom, with Simon Fuller's producer against Simon Cowell and the production companies Syco and Fremantle Media, for the copyright infringement of the format of Pop Idol by Cowell's creation, $X$ Factor.

21 "By your side I feel safe," from 'Mi música es tu voz,' which was initially written by the contestants Juan Camus and Naim Thomas and was then produced by the already established singer, Alejandro Abad, it was sung by the sixteen OT1 contestants. Click here for more information.

22 Gestmusic Endemol, Shine Iberia, Zeppelin TV, Diagonal TV, Endemol Portugal and all their controlled companies.

23 Rafa Rodríguez, 'El proyecto anduvo año y medio cogiendo polvo en los cajones de todas las cadenas, hasta que TVE decidió rescatarlo,' Las Cifras Del Negocio in Operación Triunfo, December 2001.

24 The data about the first Spanish edition are drawn equally from the book Quince años de Gestmusic, Tallers Gráfics Alemany, Barcellona, 2002; the 'format bible' of Operación Triunfo; as well as from interviews at the Format Department of Endemol Italia, the Press Office of RTVE, the Departamento de Producción of Gestmusic Endemol and at Portalmix, the official website of the production in 2002. 
Each week, during the prime-time show, they had to sing a song chosen by the professors of the school, which they had been preparing during the various lessons. A jury of six experts in the Spanish music market drew up a ranking. The last four winners were at risk of expulsion. The candidate considered the best by the home audience through phone calls and short message services (SMS) was automatically saved. Teachers had the right to save one of the nominees due to their special merits, which had been shown during the week; other contestants could save another one. The two remaining contestants were submitted to the vote of the audience from home, and the eliminated candidate was announced live during the following prime-time slot.

For the three finalists, the production was committed to promoting a career through the recording of a CD. The winner would have the honour of representing Spain in the Eurovision Song Contest that took place in Tallinn, Estonia, in 2002.

Every week, a CD with the songs presented live was quickly recorded and sold a week later at a very low price and was distributed in supermarkets, train stations, and kiosks as well as through the typical music distribution channels. To complete the preparation, the contestants received visits from some important artists who were particularly interested in the promotion of their tour or album: ${ }^{25}$ Sting, Anastacia, Miguel Bosé, Laura Pausini, Shakira, and Lenny Kravitz among others. Even Paul McCartney received a visiting group of the students and professors of the Academia.

\subsection{TVExploitation}

Galas, Resumen diario, and Resumen del domingo occupied the weekly schedule of TVE1 and TVE2 from October 2001 to February 2002 for approximately five hours each. News and other programmes slowly started speaking about the programme and triunfitos daily. By the third Gala, the audience had already doubled. While the average share of network prime time for TVE1 in the same period was $27 \%$, the average of Gala's share was $43.37 \% .{ }^{26}$ The final Gala was followed by 12.873 million viewers from a population of 35.244 million inhabitants, with a share of $68 \%$ ! The daily version on TVE2 registered an average audience of 3.037 million viewers and an average share of $19.3 \%$, compared to the very low average network audience, which was then $7.6 \%$.

Given its incredible success, after the final Gala, the programme was continued until March $11^{\text {th }}$ in order to choose the Spanish representative for the Eurovision Song Contest from among the three finalists.

At the end of programme, the triunfitos started a period of concerts and promotion, and RTVE took the chance to follow its creations. Triunfomania was then launched, following the tour of the competitors, who gave 29 concerts in 23 towns,

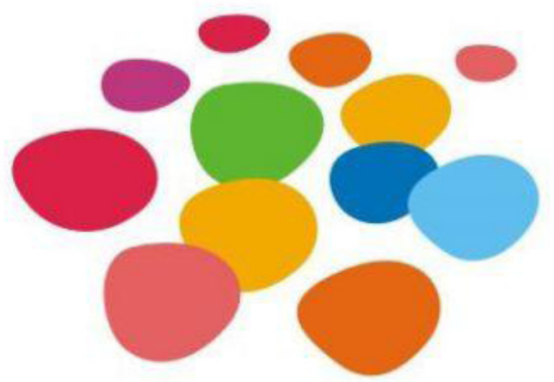

\section{EUROVISION SONG CONTEST ESTONIA 2002}

Figure 4. Eurovision Song Contest - 2002 Logo. Click here to see the source.

25 The official website of the programme had a special area for the albums of the guests.

26 Audience data from Taylor-Nelson/Sofres A.M. and Estudio General de Medios de la Asociación para la Investigación de Medios de Comunicación - AlMC. 
P. Savini, Remembering Operación Triunfo

registering 60,000 people in the Santiago Bernabeu stadium in Madrid. The programme was aired on TVE1 and TVE2 on Monday, and it was seen by an average audience of 3.68 million viewers, with an average audience share of $29.53 \%$.

Gestmusic produced three other prime-time shows that were based on the personal success of the three finalists, and these were called, respectively, Bustamante $y$ amigos, ${ }^{27}$ Bisbal y amigos, ${ }^{28}$ and Rosa $y$ amigos. ${ }^{29}$ The latter programme officially ended the first edition of Operación Triunfo on 2 July 2002.

Overall, in 2002, TVE1 and TVE2 recorded an audience average increase exceeding 4\%. Moreover, OT1 also helped the networks appeal to a young audience, those between 16 and 24 and between 25 and 29 years of age who, from an average of $18.5 \%$, increased respectively to $43.5 \%$ and $42.2 \%$. Children also liked the programme, as an average share of $17.9 \%$ and $18.3 \%$ became $44.9 \%$ and $46.5 \%$, for those between 4 and 9 and 10 and 12 years of age, respectively.

While RTVE's expenses for the acquisition of the programme and its production were high, ${ }^{30}$ economic revenues were exceptional. In addition to broadcasting over RTVE, from 27 December 2001, the programme kicked off something unusual for Spain: a thematic channel that was dedicated entirely to OT1, hosted on the platform Canal Satélite Digital, and which was named Canal Operación Triunfo.

\subsubsection{Eurovision Song Contest}

Rosa López represented Spain at the Eurovision Song Contest, which was held on 25 May 2002, in Estonia. She was accompanied on the journey by five triunfitos, who served as a choir. The song with which Rosa participated was 'Europe's living a celebration', a real smash during spring/summer 2002.

Video 4. Rosa: 'Europe's living a celebration' song. See the original source here. Go to the online version of this article to watch the video.

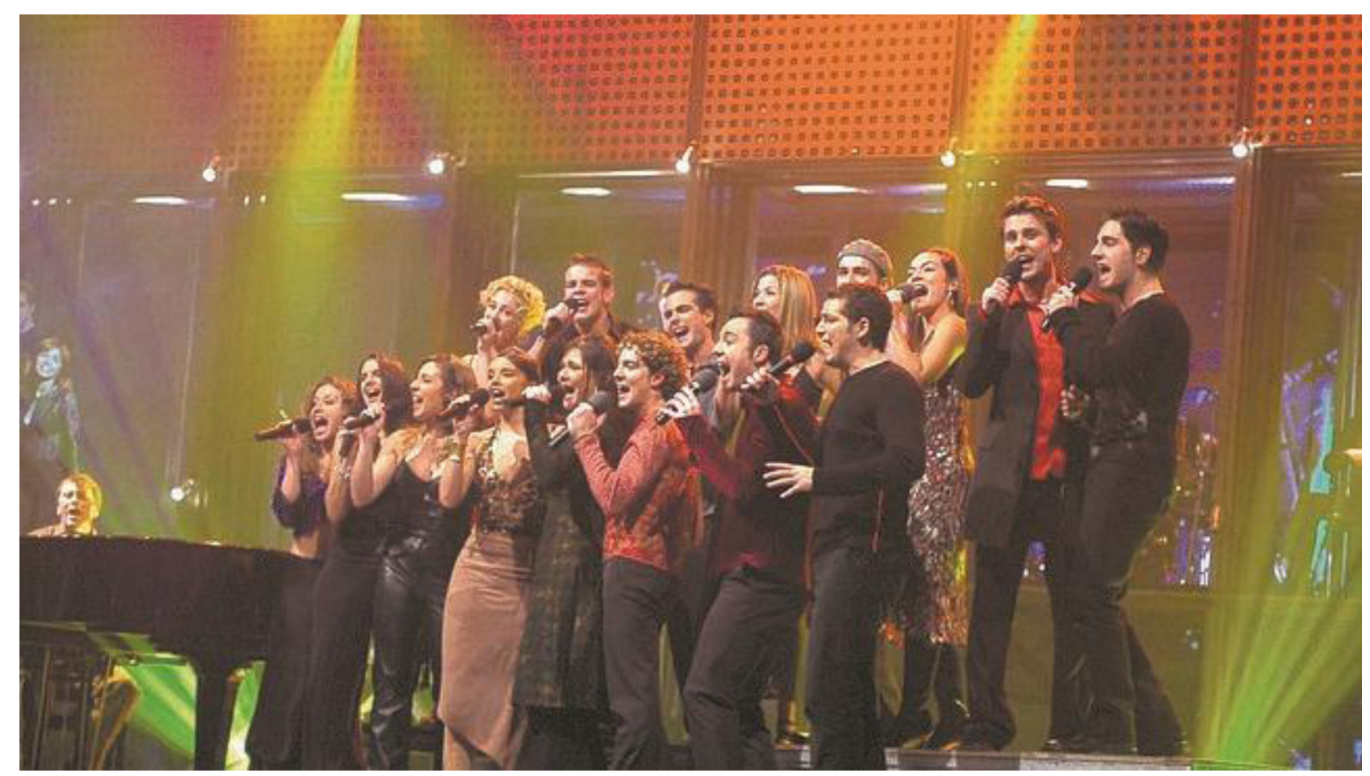

Figure 5. OT1 - The competitors Source: RTVE.

27 Live from Santander, 18/06/2002, average of 3,064,000 and audience share of $20.8 \%$.

28 Live from Almería, 25/06/2002, average of 4.613 .000 and audience share of $33.3 \%$.

29 Live from Granada $2 / 07 / 2002$, average of 4.463 .000 and audience share of $31.9 \%$.

$30 € 7,200,000$ plus $€ 3,000,000$ for the Academia, and an average of $€ 90,000$ per competitor, in Perspectivas del mundo de la comunicación, 10, 2002, Facultad de Comunicación, Universidad de Navarra, Pamplona. 
Spain did not win the competition, however. The Eurovision Song Contest was integrated into a programme that was more than four hours long, called Operación Eurovisión, with an average audience share of $40 \%$. Three hours before the competition, Gestmusic produced a special programme live from Granada, Rosa's birthplace, which was broadcast by TVE1. The Eurovisión Festival, for the executive production of RTVE, obtained an audience share of $80.4 \%$, reaching $86.2 \%$ during the vote, with an average of nearly 13 million viewers $(12,755,000)$. The Eurovision Song Contest is historically one of the most viewed TV programmes in Spain, as in the rest of most European countries, but Tallinn's edition was unique. Until 2016, Spain took part in the competition 55 times; however, it won on only two occasions $(1968,1969)$. The method by which the Spanish performer is selected has been changing continuously over the years (mainly RTVE internal audits and music competitions have been used), but the association with Operación Triunfo was reinforced by the 2002 TV success. However, RTVE did not replicate those numbers, neither by selecting Operación Triunfo winners (in 2003 and 2004) nor in any other way. The carryover effect of OT1 was not reproduced, and despite the continuous attention from the press, the multimedia platforms, and the social network sites that emphasise the event, since 2004, the audience share exceeded 50\% only in 2008.

\begin{tabular}{|c|c|c|c|c|c|}
\hline Year & Location & Performer & Audience & Share & Performer's Selection \\
\hline 1992 & Sweden & Serafín Zubiri & $3,005,000$ & $25.4 \%$ & \multirow{8}{*}{$\begin{array}{c}\text { RTVE } \\
\text { internal audit }\end{array}$} \\
\hline 1993 & Ireland & Eva Santamaría & $5,053,000$ & $42.2 \%$ & \\
\hline 1994 & Ireland & Alejandro Abad & $3,037,000$ & $26.1 \%$ & \\
\hline 1995 & Ireland & Anabel Conde & $4,458,000$ & $35.5 \%$ & \\
\hline 1996 & Norway & Antonio Carbonell & $3,650,000$ & $27.5 \%$ & \\
\hline 1997 & Ireland & Marcos Llunas & $3,224,000$ & $30.3 \%$ & \\
\hline 1998 & $\begin{array}{l}\text { United } \\
\text { Kingdom }\end{array}$ & Mikel Herzog & $4,145,000$ & $32.3 \%$ & \\
\hline 1999 & Israel & Lydia & $3,950,000$ & $34.2 \%$ & \\
\hline 2000 & Sweden & Serafín Zubiri & $4,056,000$ & $34.8 \%$ & \multirow{2}{*}{ Eurocanción } \\
\hline 2001 & Denmark & David Civera & $5,614,000$ & $45.7 \%$ & \\
\hline 2002 & Estonia & Rosa López & $12,755,000$ & $80.4 \%$ & \multirow{3}{*}{ OT } \\
\hline 2003 & Latvia & Beth & $8,790,000$ & $58.4 \%$ & \\
\hline 2004 & Turkey & Ramón & $6,826,000$ & $50.1 \%$ & \\
\hline 2005 & Ukraine & Son de Sol & $4,712,000$ & $35.5 \%$ & $\begin{array}{l}\text { Eurovisión 2005: Elige } \\
\text { nuestra canción }\end{array}$ \\
\hline 2006 & Greece & Las Ketchup & $4,892,000$ & $38.9 \%$ & $\begin{array}{c}\text { RTVE } \\
\text { internal audit }\end{array}$ \\
\hline 2007 & Finland & D'Nash & $3,373,000$ & $28 \%$ & Misión Eurovisión \\
\hline 2008 & Serbia & $\begin{array}{l}\text { Rodolfo } \\
\text { Chikilicuatre }\end{array}$ & $9,336,000$ & $59.3 \%$ & Salvemos Eurovisión \\
\hline 2009 & Russia & Soraya Arnelas & $5,122,000$ & $35.9 \%$ & Eurovisión 2009: El retorno \\
\hline 2010 & Norway & Daniel Diges & $5,760,000$ & $41.9 \%$ & $\begin{array}{l}\text { Eurovisión 2010: Destino } \\
\text { Oslo }\end{array}$ \\
\hline 2011 & Germany & Lucía Pérez & $4,724,000$ & $32.3 \%$ & Destino Eurovisión \\
\hline 2012 & Azerbaijan & Pastora Soler & $6,542,000$ & $43.5 \%$ & $\begin{array}{c}\text { RTVE } \\
\text { internal audit + Eurovisión: } \\
\text { Pastora Soler }\end{array}$ \\
\hline 2013 & Sweden & $\begin{array}{l}\text { E1 Sueño de } \\
\text { Morfeo }\end{array}$ & $5,369,000$ & $33.1 \%$ & $\begin{array}{l}\text { El Sueño de Morfeo: } \\
\text { Destino Eurovisión }\end{array}$ \\
\hline 2014 & Denmark & Ruth Lorenzo & $5,141,000$ & $35.2 \%$ & Mira quién va a Eurovisión \\
\hline 2015 & Austria & Edurne & 5,9 & $39.3 \%$ & $\begin{array}{c}\text { RTVE } \\
\text { internal audit }\end{array}$ \\
\hline 2016 & Sweden & Barei & $4,292,000$ & $29.8 \%$ & Objetivo Eurovisión \\
\hline
\end{tabular}

Figure 6. Eurovision Song Contest Spanish Editions (1992-2016): Audience, Performers and Selection Method. The data is extracted from different sources, such as: www.historia.foroeurosongcontest.es, www.vertele.com, www.eurovision-spain.com, www. eurovision.tv, www.rtve.es/television/eurovision, Wikipedia. 
Video 5. Eurovision Song Contest's Greatest Hits 2015 - Rosa. Go to the online version of this article to watch the video.

\section{Source: RTVE.}

What has been done through advertising and promotion to launch OT1 and its artists was incredible for those years. Radio, Internet, satellite TV, and merchandising joined forces to create a socio-economic phenomenon that had no precedence in Spanish TV. Products marketed under the OT1 brand numbered about 200, with 22 different licensors. A magazine was created, called Operación Triunfo. However, musical success and Internet results were huge.

\subsection{The Music Market: 'Te Cambiamos Tu Disco De Operación Triunfo Por Uno De Verdad'31}

According to the Sociedad General de Autores Españoles (SGAE), in 2002, OT1 saved the Spanish music market. The programme created a parallel market in which the supply and demand for music produced, distributed, and promoted by the big TV machine was operated properly, while piracy was slowly eating into the then known physical market of CDs. This actually did not mean that the music market in general benefited from the programme, but something certainly happened. Radios were airing the songs from the programme repeatedly. Triunfitos were everywhere.

As was noticed, ${ }^{32}$ the strategy adopted in the programme was innovative for the industry, influencing the way that CDs were produced, lowering the price (€6 on average), and introducing new customers to the market. Moreover, music

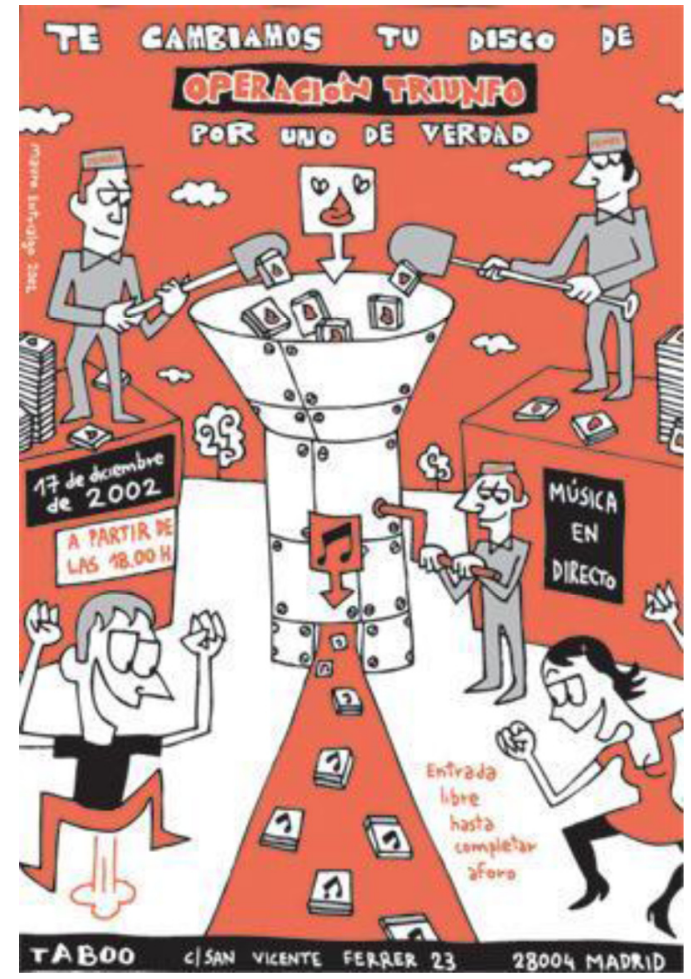

Figure 7. 'Otro Timo No', 2002. Source: PEMOC.

31 "We Exchange your OT CD with a real one," from PEMOC (Association of Journalists Specializing in Music, Leisure and Culture) poster, 'Otro timo no,' December 2002.

32 Fouce Héctor and Silva Martínez, From Opacity to Transparency: Operación Triunfo and New Trends in Spanish Music Industry, Proceedings of the 12th Biennal International IASPM Conference Montreal, 2003, pp. 210-19. 
promotion on TV was suddenly abundant, while it had previously been almost unnoticed in the Spanish market. Finally, the live concert industry was also changed. During OT1, before people were accustomed to the programme in its following editions, critics from the music world were abundant. ${ }^{33}$

From the Galas, 14 CDs were sold at $€ 5.98$ each, with a total of $1,900,000$ units.

The collection Oferta Galas sold 2,000 units at $€ 80$ each.

Gala Eurovisión sold 500,000 units at $€ 5.98$.

The Christmas album OperaciónTriunfo Álbum sold 1,200,000 units at $€ 16.20$ each, and Operación Triunfo sings Disney sold 740,000 units at $€ 18$ each. ${ }^{34}$

Album Eurovisión sold 140,000 units at $€ 11.50$.

The album Operación Triunfo en concierto sold 25,000 units at $€ 13.50$ each.

Disco del Deporte, where Triunfitos sung a hymn ('Vivimos la Selección') during the World Cup Korea-Japan 2002, was also sold at $€ 5.98$.

Every week singles were also sold at $€ 5.98$ each.

Competitors sold many CDs:

David Bisbal (second place) sold1.500.000 units ${ }^{35}$

Rosa López (the winner) 550,000

Bustamante (third place) 500,000

Manu Tenorio 500,000

Chenoa 400,000

Nuria Fergó 320,000

Gisela 180,000

Fórmula Abierta 170,000

Natalia 150,000

Alejandro 130,000

Naim 110,000

Verónica 80,000

Juan 30,000

In the last decade, seven of the 16 triunfitos of OT1 have been professional singers, ${ }^{36}$ and some are still very famous. ${ }^{37}$ In October 2016 a reunion of the OT1' singers has been planned by RTVE, featuring a concert and three documentaries about the first edition.

Video 6. Viaje al centro de la tele - Después del triunfo (I), 2015. See the source here. Go to the online version of this article to watch the video.

From the sale of albums and singles during OT1, RTVE, Gestmusic Endemol, and the small record company Vale Music received $€ 36,000,000$, until $2002 .{ }^{38}$ A film was also produced, OT. La Película, directed by Jaume Balagueró and Paco Plaza, which was released in theatres in Spain and was on sale as a home video, selling 500,000 copies, which were distributed by Manga Films.

33 See: http://www.elmundo.es/especiales/2001/12/television/operacion_triunfo/profesores.html or Eugenio De Los Ríos and Rafa Rodríguez, 'El reparto del botín. Operación triunfo: la traca final,' 1 February 2002.

34 Synergy was strengthened when three of the four boys in the group Fórmula Abierta were called upon to interpret the musical 'Peter Pan.'

35 With 'Corazónlatino,' at $€ 9.50$, soaring the first year.

36 http://www.lavanguardia.com/television/20131022/54392282003/operacion-triunfo-ot-doce-anos.html.

37 David Bisbal sold more than 5 million albums and earned many Platinum records, with more than 600 concerts all over the world, winning also two Latin Grammys, a Billboard Latinos and the World Music Artist Award as 'Mejor Artista Latino del Mundo.' Bustamante also sold more than 2 million albums and singles in Spain and Latin America.

38 Source: telephone interview at the Press Office of RTVE, May 2003. 
At the MIPTV 2003, which was held in Cannes on March $25^{\text {th }}$ in the Palais de Festivals, a competition among the national winners of the Endemol format that proceeded from Starmaker was organised. For Spain, Chenoa, singing 'It is raining men', won against the eight competitors of Fame Academy (UK), Star Academy (France and Belgium), Starmaker (Netherlands), Factory of the Stars (Russia), Fame Story (Greece), Academia de Estrellas (Portugal), and Operazione Trionfo (Italy).

\subsection{Audience Participation Through Internet and Phone: "The Way We Were'39}

As for the programme's official website, this was host to an independent portal, Portalmix SL, which began three years before. In addition, OT1 registered 130 million page views from October 2001 to March 2002. During the final stage, Portalmix received 4.5 million visits a month. During the broadcast, TV had an influence of $35 \%$ on the traffic of the portal, and when the programme was over, it continued to exercise an influence of about $17 \%$, according to the then director.

There were also traditional forms of community, such as the forum, 'La Revista', with a total of 8 million messages being left between March 2002 and 2003. The triunfitos received 2 million SMS during OT1, which were sent through the portal and received on special phones that the production organisation gave them. During the first edition, RTVE earned $€ 2,602,045.60$ from phone calls and $€ 92,856.37$ from the messages sent through the Internet. ${ }^{40}$

A 'Club OT' was created as an association into which viewers could enter by paying €25, this allowed members to browse internal sections and to have contact with the guys through meetings and concert tickets as well as discounts on merchandising. The membership card was also used to make purchases through the site.

Among other major initiatives that were developed, there was the offer 'Operación Internet,' an ADSL connection offered by Terra España ${ }^{41}$ sold together with the membership card of Club OT. The offer, at $€ 42$ per month, was promoted through the TV show.

\subsection{Afterthe First Edition}

The second edition, from October 2002, decreed a new season of success, albeit on a much smaller scale. Year after year, things were slowly changing in the format.

\begin{tabular}{|c|c|c|c|c|}
\hline Show & Channel & Season & Share & Average Share \\
\hline OT1 & TVE & $2001-2002$ & $6,947,000$ & $43.3 \%$ \\
\hline OT2 & TVE & $2002-2003$ & $5,584,000$ & $36.4 \%$ \\
\hline OT3 & TVE & 2003 & $3,412,000$ & $22.5 \%$ \\
\hline OT2005 & Telecinco & 2005 & $4,847,000$ & $37.6 \%$ \\
\hline OT2006 & Telecinco & $2006-2007$ & $4,312,000$ & $26.9 \%$ \\
\hline OT2008 & Telecinco & 2008 & $3,830,000$ & $26.9 \%$ \\
\hline OT2009 & Telecinco & 2009 & $2,509,000$ & $18.6 \%$ \\
\hline OT2011 & Telecinco & 2011 & $2,282,000$ & $13.9 \%$ \\
\hline
\end{tabular}

Figure 8. Prime time rating. Source: Gestmusic Endemol website on Taylor-Nelson/Sofres A.M. data.

39 Barbra Streisand, the single from the album The Way We Were, Columbia, 1973.

40 During the second edition of the Programme, and thenceforward, a significant economic change was the introduction of the obligation to send an SMS only through personal mobile phones.

41 Terra Networks S.A. was then the first Spanish provider, and today, since 2005, is a brand within the Unidad de Negocios Digitales de Telefónica, integrated within the Spanish incumbent Telefónica De España, S.A.U. 
After three seasons on TVE, the format was acquired by Telecinco and was aired for five editions, up to 2011, when it was cancelled, owing to bad ratings. When the commercial broadcaster acquired the right to use the format, the format itself was adapted to new needs (Telecinco's direction, editorial rules, audience preferences), changing its naïve nature and reflecting an difference already seen among public service attitudes and commercial ones. ${ }^{42}$

Video 7. Last episode - OT11 'Los chicos se despiden'. See the original source here. Go to the online version of this article to watch the video.

The music market started accepting the format, and the first incredible injection of records was not replicated, even if other triunfitos achieved some fame, sometimes in South America, due to the programme. Since 2006, and strongly in 2009, those characteristics that made OT1 a good 'role model' for reality shows disappeared. Moreover, other music formats were acquiring appeal in Spain, such as Factor X (2007-2008), El Número Uno (2012-2013), and La Voz (2012-), where one of the judges was David Bisbal from OT1, but there was also Tu cara me suena (2011-) as well as the children's versions of the same programmes, and there was no more space for the very Latin and naïve flavour that had been expressed by OT1. However, none of the musical talent reached the OT1 results in any way.

This best-effort show was easily considered to be 'white', ${ }^{43}$ full of positive values, such as partnership, humility, coexistence, self-denial, and the ethics needed for identity formation, and reconciliation with the excluded and those who were failures, ${ }^{44}$ against the conflict and personal tensions that were typical of other TV shows. A relationship between two competitors (Chenoa and Bisbal) was gently emphasised, almost hidden by the cameras.

This music reality show, where the lives of the TV contestants who were enclosed in the school were constantly under observation without voyeurism, as was also the case in Amici di Maria De Filippi (initially called Saranno Famosi, 2001-) in Italy, differently from the more recent musical talents where educational aspects are less marked, expresses a TV style that is post-Big Brother, but, at the same time, that is part of a traditional world of entertainment, which is strongly linked to the needs that were expressed by the 1980s TV of 'ordinary people'.

The rise to fame was based upon hard work, talent, and being part of a community. However, the construction of the star was also a TV construction, which was helped by physical appearance, personal appeal, editing, direction, storytelling, and the transformation of the human being into a commodity to be sold on the market, but always under a moralistic umbrella, ${ }^{45}$ under the tutelage of the RTVE network (as in the case of the competitors' relationships or in the case of the physical appearance of the winner, Rosa).

The absence of official online videos, due to the lack of an agreement between RTVE and Gestmusic on the rights to distribute fragments of the OT1 edition, contributed to the creation of an aura of emotionalism, and it raised the triunfitos of the first edition to the Olympus of the Spanish Idols. Moreover, today, OT1 is a nostalgia programme and is remembered in this way.

Video 8. Para todos la tele:'Operación Triunfo'. Go to the online version of this article to watch the video.

42 See Pia Mejbrit Jensen, 'Danish and Australian Television: The Impact of Format Adaptation,' Media International Australia Incorporating Culture and Policy, Vol. 124, 2007.

43 Victor Sampedro, 'Telebasura: McTele Y ETT,' Zer. Revista de Estudios de Comunicación, 3, 2002.

44 Mariano Cebrián Herreros, Estrategia multimedia de la televisión en Operación Triunfo, Ciencia 3, 2003.

45 Wenceslao Castañares Burcio, La televisión moralista: valores y sentimientos en el discurso televisivo, Editorial Fragua, 2006. 


\subsection{Si tú no vuelves:46 The 'Latin Taste'Abroadon the Italian Version}

Operazione Trionfo was the name of the Italian adaptation that was produced by Endemol Italia and aired on the commercial broadcaster Italia 1 from September to December 2002. Even if the programme was launched with a very aggressive advertising campaign, which attempted to sell an expressly 'Latin' programme, with a red and yellow logo, with Spanish hits performed, with the Spanish but well-known anchor, Miguel Bosé, the magic of OT1 Spanish edition did not happen in Italy. Within the Italian edition, various ingredients were combined to create a positive aura; values were magnified, such as sacrifice to get results, achieving goals through work, the conquest of a dream, the undeniable 'gift', the reassuring presence of 'professors', and the constant support of the parents. However, the uncertainty between a commercial teen-oriented broadcaster, the contemporary success of Big Brother, and such a naïve image that the country was already represented by the native format Saranno Famosi did not produce the expected results. The audience shares were good, as the average prime-time share was $13.9 \%$, which is higher than the average of the network in the same period, ${ }^{47}$ but the TV community as well as the music consumers did not join the communication project. In 2011, the Italian public service broadcaster RAl tried again to work on the same format, adapting the original version of Star Academy, thus avoiding any reference with the more 'Latin' Spanish version but, unfortunately, with a bigger failure than eight years before. ${ }^{48}$

\section{Conclusions}

The current success of musical reality shows and talent shows is clear, and this can be explained by considering a few factors. Music on TV is gaining new life in current schedules all over the world.

For the music part, one role is played by the end of the vertical and top-down experience of the music charts and by the liquid digital market that has transformed music supply and demand with an injection of singles that can be sold easily on digital platforms. This new market opens spaces for economic singles that are sponsored by TV and radio in the interest of the very young buyers (young adults and teenagers) and in the interests of the recording industry, the broadcasting world, both TV and radio. The recording industry is, of course, interested in producing and selling fast cooking music. Singing covers is a business and a way to maximise profits with low investment, and on the other hand, it is a way to connect the audience with the past, recreating a family-oriented living room in front of the screen. The very fast production and distribution of singles or collective albums is the key to benefitting immediately from TV success. ${ }^{49}$

On TV's part, the matter is much more complicated, since music reality shows and talents can be easily considered within make-over TV, where the transformation of ordinary people into celebrities (as well as the chance offered to celebrities to experience new lives through participation in celebrities' talents) offers the foundation from which to make dreams come true. ${ }^{50}$ This is written in destiny, as recalled by the words stars, idols, triunfo, fame, and $x$ factor in the titles. At the same time, these kinds of popular TV shows tend to become cultural projects, creating a link to national identity through huge auditions in different national locations, through connecting the more isolated suburbs to the

46 Miguel Bosè, Lanfranco Ferrario, Massimo Grilli, Bajo el Signo de Caín, 1992.

47 Source: Auditel data.

48 http://www.tgcom24.mediaset.it/televisione/articoli/1024906/star-academy-fa-flop-e-chiude-senza-facchinetti.shtml.

49 Fouce \& Martinez 2003.

50 See: Holmes, 2004a and Gunn Sara Enli, 'Mass Communication Tapping into Participatory Culture: Exploring Strictly Come Dancing and Britain's Got Talent,' European Journal of Communication, 24, 2009, pp. 481-93. 
greatest auditoriums, and through the call to be part of a national family, to become an American Idol, an Australian Idol, or an Indonesian one. ${ }^{51}$ Moreover, everyone can participate in these democratic selections, but only those who have the talent can rise from the masses. Often, the more talented are particularly underprivileged because of their social class or due to some physical impediment, and this rise to the privileged élite is particularly appealing to the public, as the case of the British singer Susan Boyle has proved ${ }^{52}$ and, in some ways, the OT1 winner, Rosa López, who was renamed Rosa de España. ${ }^{53}$ The deep similarity of these shows' constitutive dynamics with those that characterise the shape of contemporary work, which constantly exposes the worker to the stares and judgements of others, the sense of contingency, and the endless possibilities as well as being the victim of the unexpected are other aspects that explain the success of these formats. ${ }^{54}$

Finally, no music format can be explained without continuous audience participation, on stage during the auditions and through prime-time shows, particularly the participation of voters and commentators, through the chance to participate offered by social networks and microblogging. It is a physical and virtual participation in the event and an opportunity to be part of a community of fans. The songs chosen, the judges as teachers or artists, and the contestants as performers (or as 'good guys' ${ }^{55}$ or role models) can be judged and discussed on social network sites. This new kind of participation characterises the last 10 years of audience participation in TV shows and is both a source of revenue ${ }^{56}$ and a way to create viral stars that can be easily moved from TV to radio, YouTube, Facebook, Twitter, etc.

Ten years before, things were slight different, as the OT1 case study can show. It was able to overwhelm the Spanish audience with ratings that were incredible for a music programme. It contributed to the transformation of the music market years before the digital revolution was firmly established, and the industry for live concerts was also changed. It opened new ways to interact with the public, giving nourishment to the Internet and the fan communities that were arising. It stabilised the calls from home as well as the SMS as a voting practice with high economic results.

In these ways, it created enormous economic interests and gave life to music stars, who are still famous today. It received massive criticism from the music world but, at the same time, it was able to overcome this.

All of this was Operación Triunfo in 2002, and, despite everything, history was made by TV in the music format. However, the star of the logo shined only for a few years, and the magic of the first Spanish edition has not been replicated in the following TVE editions, in the Telecinco adaptation, or abroad. When the 'Latin' attributes of the first Spanish version were highlighted, such as in the Italian version, a failure in the communication project has been identified, and the global aspects outlined by the editorial team did not obtain something that, years after, other music talents reached due to the US and British music star systems.

\section{Discla imer}

Responsibility for the information and views set out in this article lies entirely with the author.

51 See: Joost de Bruin and Koos Zwaan, Adapting Idols: Authenticity, Identity and Performance in a Global Television Format, Ashgate Publishing, 2012; Also: Cowell, 2003.

52 See Enli 2009.

53 Nickname given by the producer Alejo Stivel. See: Miguel Á. Bargueño, 'Rosa ¿De España?,' Los 40 Principales,' 25 July 2002.

54 See: Oliva-Rota, Mercè, 'Fama y éxito profesional en "Operación Triunfo" y "Famaj a bailar!," Comunicar: Revista Científica de Comunicación y Educación, 20:39, 2012, pp. 185-192.

55 Mika, from No Place In Heaven, 2015, Republic Records, UMG Recordings, Inc.

56 Ruiz, 2003 
P. Savini, Remembering Operación Triunfo

\section{B i o graph y}

Paola Savini (Milan, 1979) serves as an officer within the Italian National Media Regulation Authority, having previously worked as a consultant in the media sector. Her research interest focuses on media convergence, audiovisual production and pluralism. She holds a PhD from IULM University of Milan (2012), a BA degree in Media studies from La Sapienza University of Rome (2003), a master's degree in European Studies and Global Affairs from the Catholic University of Milan and the Pázmány Péter Catholic University of Budapest (2005), and a master's degree in Antitrust and Market Regulation from Tor Vergata University of Rome (2008). 